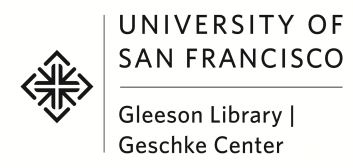

Volume 41 Fall/Winter 1994-95

Article 14

November 2014

\title{
Smart Choices for the New Century
}

Jane Anderson

Follow this and additional works at: http://repository.usfca.edu/ontarioreview Part of the Playwriting Commons

\section{Recommended Citation}

Anderson, Jane (2014) "Smart Choices for the New Century," Ontario Review: Vol. 41, Article 14.

Available at: http://repository.usfca.edu/ontarioreview/vol41/iss1/14

For more information, please contact southerr@usfca.edu. 


\title{
Smart Choices for the New Century
}

\section{A Seminar for Responsible Living}

\author{
JANE ANDERSON
}

CHARACTERS

ARDEN SHINGLES: our speaker, a woman in her 30's

RUDY: her assistant

TIME: Present

PLACE: A Lecture Hall at a Weekend Seminar

Preset is a folding table set up on stage and a lectern provided with a glass and a pitcher of water. In back of the lectern is a screen with a slide thrown up: PROTECTING YOUR LIFE.

RUDY, a guy wearing sunglasses, khakis and a gun-range cap, walks on with a case. He goes to the table, unlocks the case and lays out a couple of handguns, a can of mace and some other equipment. When he's done, he takes a seat to the side next to a slide projector.

Our speaker, ARDEN SHINGLES, comes out. She's a slim, well-groomed, energetic woman dressed in a short-skirted business suit, accessorized with high heels and a bow-tied blouse.

ARDEN: Hello everybody, I'm Arden Shingles and protecting your life is not just a privilege...

RUDY changes the slide. We see: YOUR RIGHT.

ARDEN (cont.): It's your right. But it's more than just a right...

RUDY changes the slide: YOUR RESPONSIBILITY. 
ARDEN (cont.): ...it's your responsibility.

RUDY takes the slide out. ARDEN goes to the lectern, pours herself some water.

ARDEN (cont.): I'd like to tell you a story. There was a successful saleswoman who lived outside of Austin. She was driving home late one night from the office in a brand new Lexus that her company had awarded her just that week. She hit a bump at a construction sight and her lights went out. She slowed down and her car went dead. She picked up her car phone to call for help but that didn't work either. Turns out, her battery had been replaced at the dealership and they hadn't put it in right-the bump in the road had knocked a wire loose. Now if she knew anything about cars, she could of opened up the hood and reconnected the wires. But she didn't-and lemme just throw in a sidebar here, $\mathrm{OK}$ ? This is why for years now I have been advocating that all girls take shop in high school instead of Home Ec. Let's make sure that all our young women have tire-changing skills. Let the guys learn how to make cinnamon buns, right Rudy?

RUDY: That's right.

ARDEN: You cook?

RUDY: I do now.

ARDEN: Glad you do?

RUDY: Beats waiting for my wife to do it.

ARDEN: There you go. But let's go back to our scenario. Great, so here we are, in the middle of nowhere in the middle of the night, no phone, no help, what is this woman going to do? She sees some lights coming up the road. A car pulls up, a Cadillac Seville. A nice-looking man gets out, early fifties, business suit, tie, gray at the temples-he reminds her of her boss. She glances through the window of his car, sees a briefcase on the front seat, a Business Week, a fresh cup of take-out coffee sitting in the cup holder, the steam rising up over the dash-the sight is so comforting, she almost cries. He asks if she needs help. She says, yessir, yes, she certainly does. The man walks around to the back of his car and opens up his trunk. He pulls out a knife, holds it at her chest and tells her to get in. For two hours she's trapped in the trunk while the man drives her around. She can hear him screaming obscenities at her from 
the front seat, telling her all the things he's going to do to her when they reach their destination-taking off her breasts with a hack saw being the least of it, OK? Finally the car comes to a stop. The motor is turned off. She can hear him walking around to the back. She hears him putting his key in the lock of the trunk-"Are you ready to die like the bitch you are?" he says-and as he opens the trunk, she's ready with the .38 handgun she had with her in her purse. She shoots him twice through the chest and the man falls over dead. She climbs out of the trunk, her hands still shaking, and she uses the man's car phone to call the highway patrol-fully expecting that she might be put on trial for killing a seemingly innocent businessman. When the police arrive, they tell her that they had been trying to track down the suspect of a string of gruesome murders. They said that not only did she save herself, but she saved dozens of other women from a prolonged and horrible death. That woman is alive today because she was not afraid to take responsibility for her own protection. That woman is alive because she practiced aggressive, long-term thinking. That woman is alive. That woman is me.

ARDEN goes over to a table, picks up a 38 revolver.

ARDEN (cont.): During this talk, I'm going to give those of you who've never touched a gun before an opportunity to familiarize yourself with this piece of equipment.

She snaps open the cylinder of the gun, holds it up and spins it to show that there are no bullets in the gun.

ARDEN (cont.): This is a .38 double-action revolver, which is used and recommended by most police officers. I prefer a .38 to a .22 because it has guaranteed stopping power. Many women and also men are drawn to .22's for a first gun because they feel that a .22 might be easier to handle. Which is fine, but if you have an assailant who's on crack or any of your other substances, he might not even notice he's been hit until he's back on the road, pondering what to do with your credit cards. But again, this is a personal choice. Rudy?

She hands the gun to Rudy who takes it down to the audience and gives it to a member to pass around. [Note: the gun should be real and not a prop gun. But for safety's sake, a part of it should be made inoperable.]

ARDEN (cont.): Pass it around, get to know it. This gun is not loaded, there are no bullets in the chamber. It doesn't have a mind, it doesn't have a will, it doesn't even have batteries. It is just a piece of metal, a 
collection of movable parts that do not move until you make them do so. Pull the trigger if you like. It will not hurt you. The devil is not hiding in the barrel. It is not "bad." Bad things are done by people, not by guns. Good people do not do bad things with guns. And conversely, good people do not turn bad if they have a gun, OK? We got that straight? By the year 2000, a firearm will be as common a piece of equipment as your car phone or pocket computer. This should not scare you and this should not cause you despair. This is what I do-I'm a historian; I like to compare the Then with the Now; I like to let the past be my path to the future. Here's an example: when they first started putting electricity into homes, some people said, "Oh no we can't do that, it's too dangerous, someone's gonna kill themselves." They painted these scenarios of entire families laying dead on the floor, with their fingers in the sockets and their eyeballs fried. We can look back on that now and say, "Oh that was alarmist thinking." Hindsight is easy, I agree, but before we make an instant value judgement on something, it's good to first lay a grid on it. I'm an optimist-realist. What that means is that I look at what could potentially be bad and then figure out a way to make it good.

RUDY is back at his seat, changes the slide: we see a line graph chart on projected crime rate up to the year 2000 .

ARDEN (cont.): Take a look at this chart. This is the reality, folks. I wish I could say that things in our country were getting better but sweet people, all you have to do is look at the numbers. And crimes against women are on the ever-increase. Experts tell us that by the year 2000, one out of every three women can expect to be raped, assaulted or killed. One out of three. Hey, why not just hand us the menus right now, pick one from column A, column B, column C, right? OK, but now I'm gonna show you the good news. This is my personal projection.

RUDY changes the slide to another chart with all the projections going down instead of up.

ARDEN (cont.): I'm gonna tell you something. You know who our worst enemy is? Not the rapist, not the career criminal, not the gang member. It's ourselves. "Oh, I know it's really bad out there but there's nothin' I can do about it. Boo-hoo," you know? And I meet so many women who support this non-defense kind of attitude, they say, "Oh, I don't want to have a gun, my boyfriend says it's not feminine." Well what's feminine? (pause) You know? What's feminine-to look at me, I think you'd say that I was "feminine." Rudy would you say I was feminine? 


\section{RUDY: Yes I would.}

ARDEN: There you go. But let's examine this for a minute. Is it unfeminine to want to feel safe in your own home? Is it unfeminine to want to go to the grocery store and back without obnoxious interference? How can anyone say that wanting to protect your life is not feminine? I say, how completely childish. Because if you have that attitude, you stay the victim. Which is why a lot of men don't want us to arm ourselves-"Oh no, the little lady's gonna come after me, shoot my Don Johnson off," you know. And by the way, how many of you think that "feminist" is a dirty word? Am I right? "Feminist, oh that must mean she wears pants all the time, hates men and has chin hair." I don't think so. I mean, let's look at the word itself: "feminist" comes from the root "fem," meaning feminine, and "ist" means, "one who believes." So "feminist is one who believes in being feminine." Rudy, that make sense to you?

\section{RUDY: Yes it does.}

ARDEN: See? They can learn. But we have to learn too. I know a lot of women who are ready to take responsibility for their own protection, but they say to me, “Arden, I just can't get behind using a gun." And that's a very natural reaction. As women, our traditional role has been to be life giver, not life taker. Yes, I agree with all of that. But as life giver, what am I going to do when I'm alone in a parking garage and some guy jumps between me and my car?

ARDEN picks up a ring of keys from the table, fits them between her fingers. RUDY joins her for a demonstration.

ARDEN (cont.): Here's a good one. How many of you have tried this? "OK, I'm now going to save my life with a bunch of keys sticking out of my knuckles."

RUDY does a simulated attack, disarms ARDEN then holds her in a grip.

ARDEN (cont., to audience): Now what? I am now free to be raped, disfigured and killed.

RUDY releases her. ARDEN picks up a can of mace.

ARDEN (cont.): OK, that didn't work, think I'll buy myself a can of mace and stick it in my purse. 
RUDY pretends to run at her. ARDEN holds up the can, pretends to spray. RUDY coughs twice then grabs ARDEN, holds her in the same grip.

ARDEN (cont.): Oops, guess no one told me that most mace sold on the market is so diluted that it's about as effective as a baby peeing on a rabid dog. Again, I am now free to be raped, disfigured and killed.

RUDY releases his grip. ARDEN picks up a stun gun.

ARDEN (cont.): OK, that was fun, now that all my broken ribs are healed and I've got most of my face back, I think I'll buy myself a stun gun. Now this is a great weapon. It won't penetrate a heavy coat or a leather jacket and in order for it to work at all you have to hold it against the struggling body of your two-hundred-pound assailant for a full three seconds.

ARDEN tries to zap RUDY. RUDY grabs her arms, holds the gun away from his body, then throws ARDEN into a grip, holding the stun gun next to one of her nipples.

ARDEN (cont.): Once again, it's open season on me. All right.

RUDY releases ARDEN, starts to walk back to his chair. RUDY suddenly rushes back at ARDEN. ARDEN grabs a gun from the table, and whips around taking a stance.

ARDEN: STOP RIGHT THERE! ADVANCE ANY FURTHER AND I'LL SHOOT!

RUDY immediately stops.

ARDEN: SLOWLY BACK AWAY WITH YOUR HANDS UP. IF YOU MAKE ANY OTHER MOVEMENT I WILL KILL YOU.

ARDEN backs RUDY up and makes him sit in his chair. She lowers the gun and walks back to the table, puts the gun back down.

ARDEN: Which method of defense involved no physical contact between you and your assailant? Which method of defense protected your dignity as well as your life? And which method of defense involved the least amount of violence?

(a beat) 
You know? It's like when we used to have nuclear weapons between us and the Russians. This was the greatest deterrent to war ever. But once you remove the bigger threat then everyone thinks, "Oh, it doesn't matter if I invade this country here, think I'll just sneak over, kill a couple of thousand people I don't want around anymore." You know. In other words: the more effective your weapon is, the less likely you will have to use it. What we're talking about is deterrence. Not death, deterrence.

(a beat)

See, I get crazy when people just make these blanket assumptions that all guns kill. That's like saying, oh, let's get rid of all cars because of all the highway deaths. Hey, fine with me-did you know that there are twenty times more fatalities caused by cars than by guns? And you don't see Car Control lobbies out there in Washington. You don't see anyone instituting a ten-day waiting period before you can purchase your new VW.

RUDY: That's 'cause no one would buy one if they had to think about it.

ARDEN: That's right. But hey, it's a free country.

RUDY: That's right.

ARDEN: What do you drive, Rudy?

RUDY: GM truck.

ARDEN: You like to buy American?

RUDY: That's right.

ARDEN: Where are all our guns manufactured, Rudy?

RUDY: America.

ARDEN: There you go. (To audience) By the way, the first thing Hitler did when he came into power? He took the guns away from the Jewish people. All things to think about. What tonight really is about is starting up our mental responsibility process. Tonight is about saying, "I have a right to my future, whether I'm male or female, black or white, rich or poor. I have a right to stay alive and make my contribution to this beautiful world."

RUDY walks down to the audience. 
ARDEN (cont.): Whoever has the gun, would you mind holding it up so Rudy can collect it?

RUDY gets the gun, comes back on the stage. ARDEN sits on the edge of the table while RUDY starts packing everything back into the case.

ARDEN (cont.): Isn't life funny? Lemme tell you one last story. I remember when I was a little girl, my family and I took a trip to the New York World's Fair. Anybody remember going to that? When was that, 1964, something like that-anyway, there was this one exhibit called The City of Tomorrow. We stood in this long line that eventually went into a room where you stood on a catwalk and looked down at a giant model of what a city would look like in fifty years. There were these little domeshaped houses and weird-looking towers and monorails that snaked in and out of the whole thing. And all the little people in the city looked kind of sealed in .... and I don't know, it all looked so strange to me that I got a sick feeling in my stomach. And I started to cry. And my mother asked me what the problem was. I told her my stomach hurt and she said that was because I'd been eating junk all day. And I said, no, my stomach hurt because the model of the city scared me, that I didn't ever want to have to live like that. And my father looked down at me, and you know what he said? He said, "Don't worry, Girl, by the time the future gets here, you won't notice that anything's different."

RUDY hands ARDEN the .38 and a case of bullets.

ARDEN (cont.): Thank you, Rudy. (Back to audience) One last point. What would happen if I put bullets in this gun and passed it back around?

(a beat)

Maybe that gun would just continue to be passed from hand to hand. Or maybe it would stop with that one bad apple who's sitting among you. $\mathrm{He}$ or she would hold onto that loaded gun, cock the hammer and take advantage of us one by one.

(a beat)

$\mathrm{OK}$, but what if I gave everyone a loaded gun?

(a beat)

See how it all makes sense?

ARDEN hands the bullets and the gun back to RUDY. She smiles at us and walks out. RUDY puts the gun back in the case and pockets the bullets for himself. He snaps the case shut as the lights fade out. 